\title{
若材齢モルタルの乾燥途中における細孔構造と水分状態 PORE STRUCTURE AND MOISTURE OF MORTAR AT EARLY AGES DURING DRYING
}

\author{
田中享二*, 橋田浩**, 端直人***
}

Kyoji TANAKA, Hiroshi HASHIDA and Naoto HASHI

\begin{abstract}
The method, which is based on a mercury intrusion technique, was developed to measure the porosity of mortar specimens partially containing moisture in their pores. The results obtained through the method were compared with pore size in which water condenses calculated by the Kelvin's equation and total pore volume measured by a volumetric method, then the validity of them was discussed. It was made clear from the measurement of mortars at early ages during drying that diameters of pores filled with liquid water become smaller and volumes of them decrease.
\end{abstract}

Keywords : pore structure, mortar, early age, moisture, drying, mercury intrusion technique, 細孔構造, モルタル, 若材踚, 水分, 乾燥, 水銀圧入法

1 はじめに

大気中にあるコンクリートやモルタルは、絶乾状態に あるのではなく必ず水分が含まれている。そのため内部 の細孔の一部は液相の水分で充填されている状態にある。 従って、実際の環境下にあるコンクリートやモルタルの 空隙とは、水分の凝縮していない非凝縮領域の空間と考 えることができる。

これら細孔内の水分状態の変化は、コンクリート、モ ルタルの打込み直後から始まる。製造時に混練された水 は、一部はセメントの水和に消費され、一部は細孔内に とどまり、残りは時間とともに大気中に放出される。そ れらはそれらの置かれている環境湿度に強く依存する。 この水分状態は、コンクリートやモルタルの諸物性、例 えば、強度、乾燥収縮、凍害、透気性等に密接に関与す るため、この現象の的確な把握は重要である。

そのためには水分を含む状態でのコンクリートやモル タルの細孔状態を知る必要がある。細孔構造を調べる手 段としては水銀圧入による細孔容積測定がなされるが、 この方法は試料を乾燥させる必要があるため、試料に水 分を含む状態での情報は得られない。そのため筆者等、 内川等 '”が、水銀圧入法による細孔容積測定法の手順に 工夫を加えた测定法を提案した。しかしその後の検討に
より操作過程に起因する補正の必要性が明らかになった。 この方法は通常の細孔容積測定法とは異にしている点が いくつかあり、その測定結果がどの程度信頼性があるか を明確にして、はじめてその結果についての議論が可能 となる。そのため本研究ではまず補正方法も含めた、水 分を含む状態での細孔の測定法について提案し、その有 効性について、いくつかの補足的手段により検証した。 ついでこの測定法を細孔構造が急激に変化する若材齢の モルタルに適用し、水和の進行と乾燥が同時に進行しつ つある時、水分を含んだ状態での細孔構造がどのように 変化するかを検討した。対象としては最終的にはコンク リートを目標としているが、粗骨材が入るとペースト界 面との遷移帯の影響を無視し得ず複雑となるため、ここ では研究の第一段階として、その影響の少ないモルタル を対象とした。

これに関連する既往の研究についてであるが、セメン トコンクリート、モルタルの細孔（水分の存在しない状 態での測定による）および水分との関連については、乾

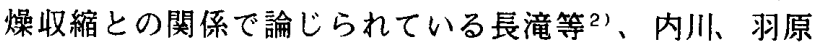
等 ${ }^{1}$ 、3)の研究、凍害との関係で論じられている鎌田等の 研究 ${ }^{4}$ 、透気性・透水性との関係で論じられている長滝 等 ${ }^{5}$ およびH.W. Reinhardt等 ${ }^{6}$ の研究がある。しかし水分

\footnotetext{
本研究の一部は 1991 年度日本建築学会大会 (東北) において発表した。

* 東京工業大学工業材料研究所 助教授 - 工博 Assoc. Prof., Research Laboratory of Engineering Materials, Tokyo

** 清水建設技術研究所・工修 Institute of Technology, Dr. Eng.

Research Engineer, Institute of Technology, Shimizu Corporation, M. Eng.

東京工業大学 大学院生

Graduate Student, Tokyo Institute of Technology
} 
が含まれている状態での細孔構造にまでたちいたって論 じられたものは少なく、筆者等の知る範囲では前述の内

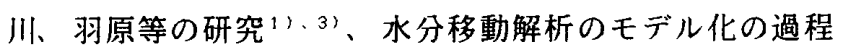
で議論された下村等の研究?'がある程度である。

\section{2 試酶体および試料の採取}

一連の実験にはフロー值 $180 \mathrm{~mm}$ 目標としたモルタルを 用いた。その調合を表 1 に示す。水セメント比はペース ト部分の細孔状態に差を設けるため $45 \%, 60 \%, 75 \% の 3$ 水準 とした。モルタルは機械練りの後、直径 $10 \mathrm{~cm}$, 高さ $3 \mathrm{~cm}$ の 塩化ビニル樹脂製の円筒型枠に打ち込み、水分の蒸発防 止のため直ちに封かん養生を行った。

これら試験体を1，3，7，28日後に脱型し乾燥を開始した。 なお試験体はその側面が図1(a)に示すようにエポキシ樹 脂で完全にシールされており、水分の蒸発は上面と下面 の 2 面からだけに限定されている。これらを湿度 $40 \pm 5 \%$ RH、温度 $20 \pm 1{ }^{\circ} \mathrm{C}$ に制御されている恒温恒湿室内に放置し 乾燥させた。また、試験体の乾燥状態を調べるために、 図 1 (b)に示す内部湿度モニタ一用の試験体も用意した。

表 1 モルタルの調合

\begin{tabular}{ccccc}
\hline 水 $/$ セ比 & $\begin{array}{c}\text { セメント } \\
\left(\mathrm{kg} / \mathrm{m}^{3}\right)\end{array}$ & $\begin{array}{c}\text { 砂 } \\
\left(\mathrm{kg} / \mathrm{m}^{3}\right)\end{array}$ & $\begin{array}{c}\text { 水 } \\
\left(\mathrm{kg} / \mathrm{m}^{3}\right)\end{array}$ & $\begin{array}{c}\text { フロー } \\
(\mathrm{mm})\end{array}$ \\
\hline $45 \%$ & 621 & 1367 & 280 & 180 \\
$60 \%$ & 467 & 1495 & 280 & 170 \\
$75 \%$ & 377 & 1583 & 283 & 175 \\
\hline
\end{tabular}

*普通ボルトランドセメント(比重 3.16$)$

**静岡県沢岡産砂 (絶乾比重 2.55 , 吸水率 $0.88 \%$, FM2.08)

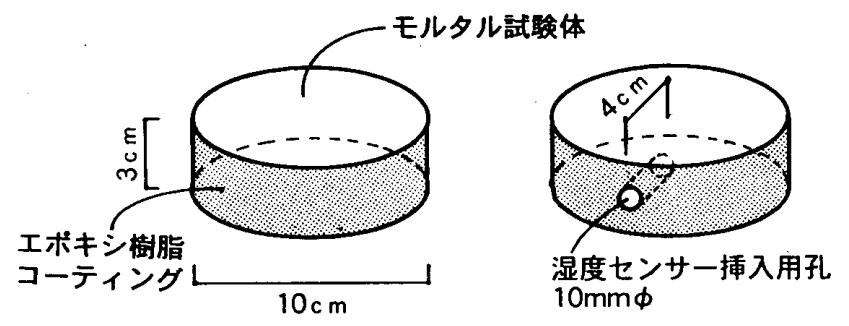

(a) 試験体

（b）湿度測定用試験体

図 1 試跧体の形状

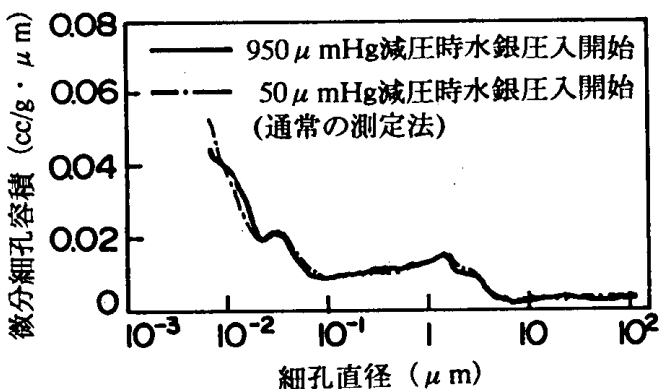

図 2 通常の隇圧と $950 \mu \mathrm{mHg}$ 減圧時の微分細孔容積の比較の一例 （水/七比：60\%,封かん鐜生28日.内部湿度85\%RH時試験体）
これには中心部分に直径 $10 \mathrm{~mm} の$ 湿度測定用の孔があらか じめ開けられており、これにペン型湿度測定センサー（ ヴァイサラ社製HMP113Y、測定範囲0-100\%RH、精度0-90\%

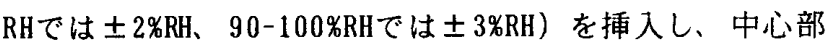
分の湿度を継続的に測定した。

試料の採取は封かん養生直後の水分蒸発前と、乾燥途 中 2 回の合計 3 回行った。乾燥途中については、乾燥速 度が調合、養生期間によって異なるため、乾燥開始後 1 日から5日の間に（モニター用の試験体の内部湿度の指 示値でおおよそ95\%RHと 85\%RHの時) 行った。所定の湿度 に到達した時に試験体をハンマーで割り、中心部分から 3〜 5mm角の小片を採取した。試料の水分の散逸を防止す るために、作業は高湿度（95\%RH以上）に保たれた恒温恒 湿室内ですばやく行い、直ちに試料瓶に入れその後の測 定に備えた。

\section{3 水分を含む状態での細孔分布の测定}

細孔分布の測定は水銀圧入法（マイクロメリテックス 社製ポロシメータ9310型を使用）により、細孔直径 $7 \mathrm{~nm}$ $110 \mu$ mの範囲で測定した。ただしここでおこなった方法 は、水分を含んでいる状態での細孔状態を測定するため、 次の 2 点で通常の手順と異なる。

まず通常の手順では測定に先立ち、試料乾燥のため D ドライ処理を行うが、本測定では水分を細孔内に保持さ せておく必要があり乾燥処理過程を削除した。次に水銀 圧入過程についてであるが、通常の湘定では水銀の細孔 内部への圧入を効率的に行う目的で、試料セル内を数十 分の時間をかけ、 $50 \mu \mathrm{mHg}$ 程度まで減压する。しかしこの 高いレベルの減压による水分散逸を、出来るだけ小さく 押さえるため、本測定では減圧開始後 $1 \sim 2$ 分程度経過 し、 $950 \mu \mathrm{mHg}$ 隇圧時に水銀圧入を開始した。この測定手 順は、筆者等が初めてその適用を試みたとほぼ同時期に 内川等"、によって、乾燥収縮をひきおこす内部応力研 究のため提案されている方法と基本的には同じである。

\section{4 本測定法の测定結果に及方す影響}

\section{1 減圧のレベルを弱めたことによる影響}

水分の散逸をできるだけ少なくするため、減圧のレべ ルを950 $\mu \mathrm{mHg}$ と弱めているが、そのため水銀が細孔内へ 入りにくくなることが予想され、測定結果に影響を及ぼ すことが㜻念される。そのため通常の測定法に従った50 $\mu \mathrm{mHg}$ まで隇圧した場合との比較を行った。比較には、水 分を含む試料は強い減圧下ではそれがほとんど散逸する ため、水分を除去した Dドライ処理後の試料を用いた。

得られた微分細孔容積曲線を図 2 に示す。ここで微分 細孔容積とは $\Delta V / \Delta \log D\left(\Delta V=\right.$ 細孔直径 $\log D_{n}$ の容積 細孔直径 $\log \mathrm{D}_{n-1}$ の容積、 $\left.\Delta \log \mathrm{D}^{2} \log \mathrm{D}_{n}-\log \mathrm{D}_{n-1}\right)$ と定義 
されるもので、特定の直径の細孔の容積がどの程度ある のかを示す物理量である。両曲線にそれほど差が見られ ていないことから、すなわちこの程度の範囲で隇圧のレ ベルを弱めたことは、測定結果にそれほど大きな影響を 与えていないと思われる。

\section{2 淢压過程における水分散逸の影響とその補正}

隇圧は $1 \sim 2$ 分のごく短時間ではあるが、それでも多 少の水分が散冕することは避けられない。その量を把握 するため、減圧により散逸する水分量（減圧前と $950 \mu \mathrm{m}$ Hg隇圧後の試料の重量差）の測定を行った。その結果、 試験体の条件によって異なるが、数パーセントから十数 パーセントの水分量散逸が測定された。この散逸量は小 さいものではなく、正しい細孔状態を知るためには、散 逸水分量に応じた補正が必要である。

その検討のため減圧のレベルを変えて測定を行い、減 王の測定結果に及ぼす影響について調べた。隇圧のレべ ルは $950 \mu \mathrm{mHg} 、 750 \mu \mathrm{mHg} 、 550 \mu \mathrm{mHg}$ 到達時の 3 段階とし た。ここでは封かん養生 1 日の試験体を例として、所定 の減圧時に水銀圧入を開始し、微分細孔容積曲線を求め た。得られた結果を図 3 左側に示す。試料の細孔内に水 分が存在しているため、特定の細孔直径からの容積が減 少するが、減圧のレベルが高くなるとそれがさらに小さ い細孔直径のほうへ移動し、また空隙となっている細孔 容積（微分細孔容積曲線で囲まれる面積で表される）も 増加する。このことは減圧のために、水分が大きい細孔 直径領域から離脱していることを意味するものと考えら れる。

\section{ところでこの減压のレべ} ルを変えた測定から次のこ とを読み取ることができる。 すなわち前述の減圧範囲で は、細孔容積の減少し始め る部分の傾きは減圧の程度 によらずそれほど変わらな いということである。この ことが水分散逸前の試験体 についても成立すると仮定 すれば、得られた微分細孔 容積曲線を散逸水分量をも とに補正し、水分散逸前の 状態を推定することが可能 となる。

そのための手順は次のと おりである。減圧過程での 水分散逸量は減圧前後の重 量差として得られる。一方 減圧後に得られた微分細孔

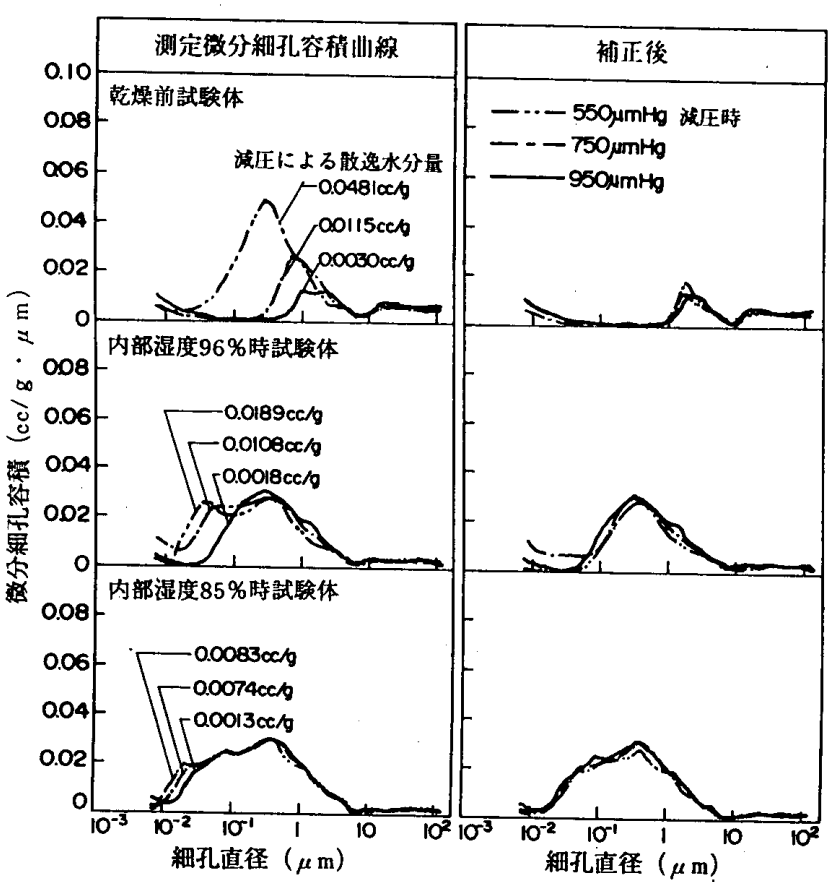

図 3 水銀圧入前の減压のレベルを変えて得られた微分細孔容皘 曲線と補正後の曲線

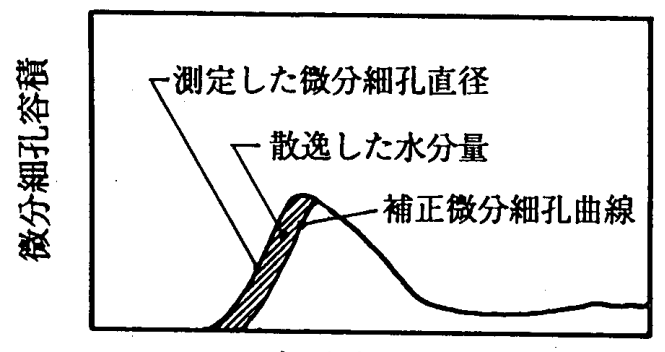

紐孔直径

図 4 散逸水分量をもとにした微分細孔容樌の補正

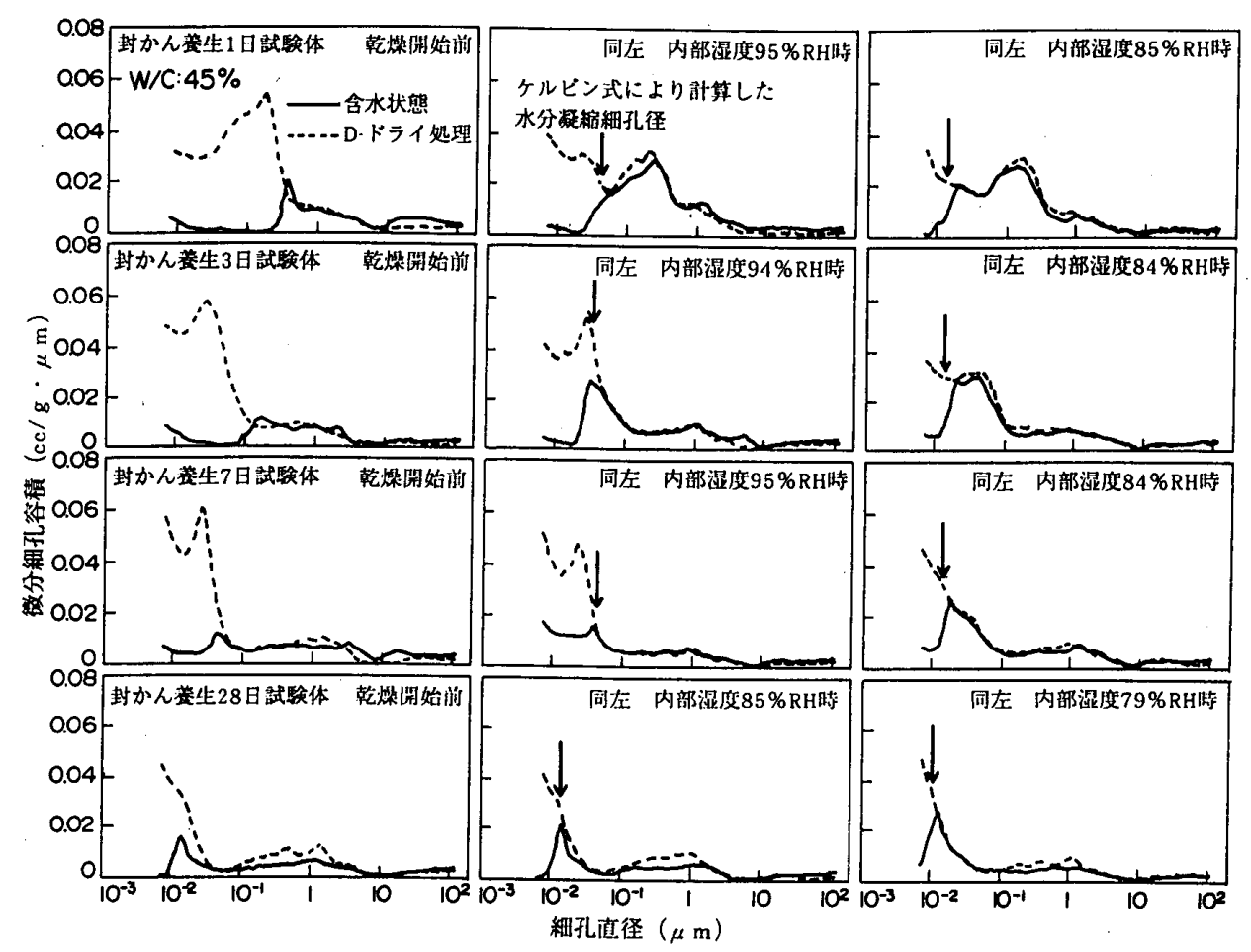

図 5（1）含水状態と乾燥処理試験体の微分細孔容積曲線（水/七比：45\%) 
曲線は、散逸した水分量だ け細孔量が多く測定されて いるはずである。従って図 4 に示すようにそれと等し い容積分だけを同じ傾きを もたせながら、細孔径の大 きい方へ移動させれば良い。 この考え方により、散逸水 分量のそれほど多くない範 囲では、どの減圧程度から でも水分散逸前の状態を推 定することが可能なはずで ある。その確認のために、 各隇圧程度ごとに得られて いる微分細孔曲線から、散 逸水分量に応じた補正を施 し、水分散逸前の曲線を推 定した。四 3 右側にその結 果を示す。必ずしもすべて が重なり合ってはいないが、 補正後の曲線はかなり同じ ような位置で同じょうな形 となっている。これはかな り良く水分散逸前の状態が 再現されていると考えられ、 従って、ここで示した考え 方による補正は可能である と思われる。

\section{5 测定結果}

図 5 に水セメント比ごと の測定結果を示す。図中、

実線が前述の方法により得 られた水分を含んだ状態で の細孔分布であり、破線が Dドライ処理を行い細孔内 の水分を除去した状態のも のである。両者を比較する と細孔直径の大きい領域で はそれほど差は見られてい ないが、細孔直径の小さい領域では特定の細孔直径から 両測定線が分離し始め、その差は急激に大きくなる。ま た乾燥が進行し内部湿度が低下するに伴い、両者の分離 し始める細孔直径は小さい方へ移動する。これらの事実 から、水分を含む試験体での細孔の状態を次のように推 定することができる。細孔直径の大きい領域での両測定 線の一致は、細孔には液相としての水分がなく空腺とし て存在していることを意味する。一方小さい細孔直径領

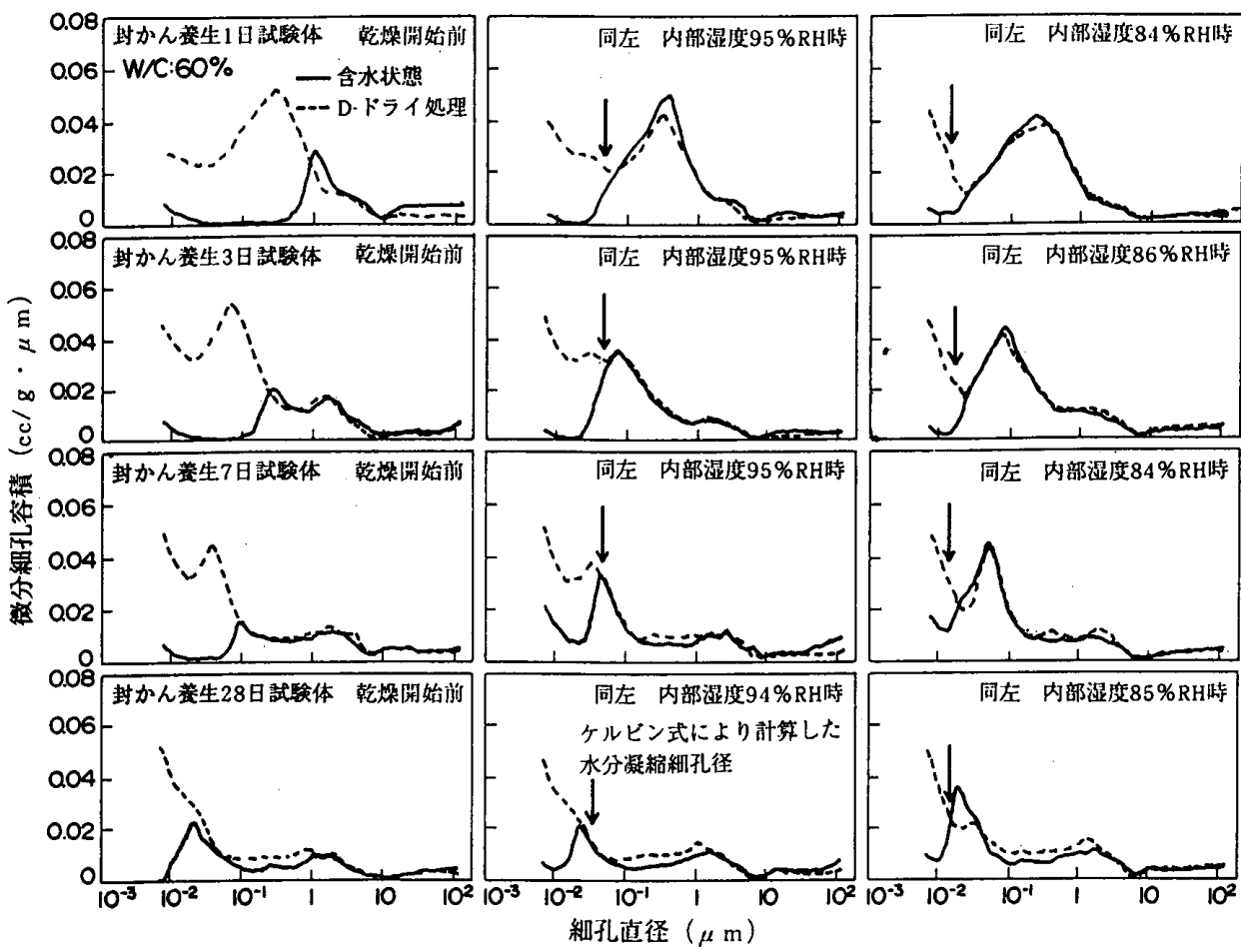

図 5（2）含水状態と乾燥処理試験体の微分湅孔容積曲線（水/七比：60\%)

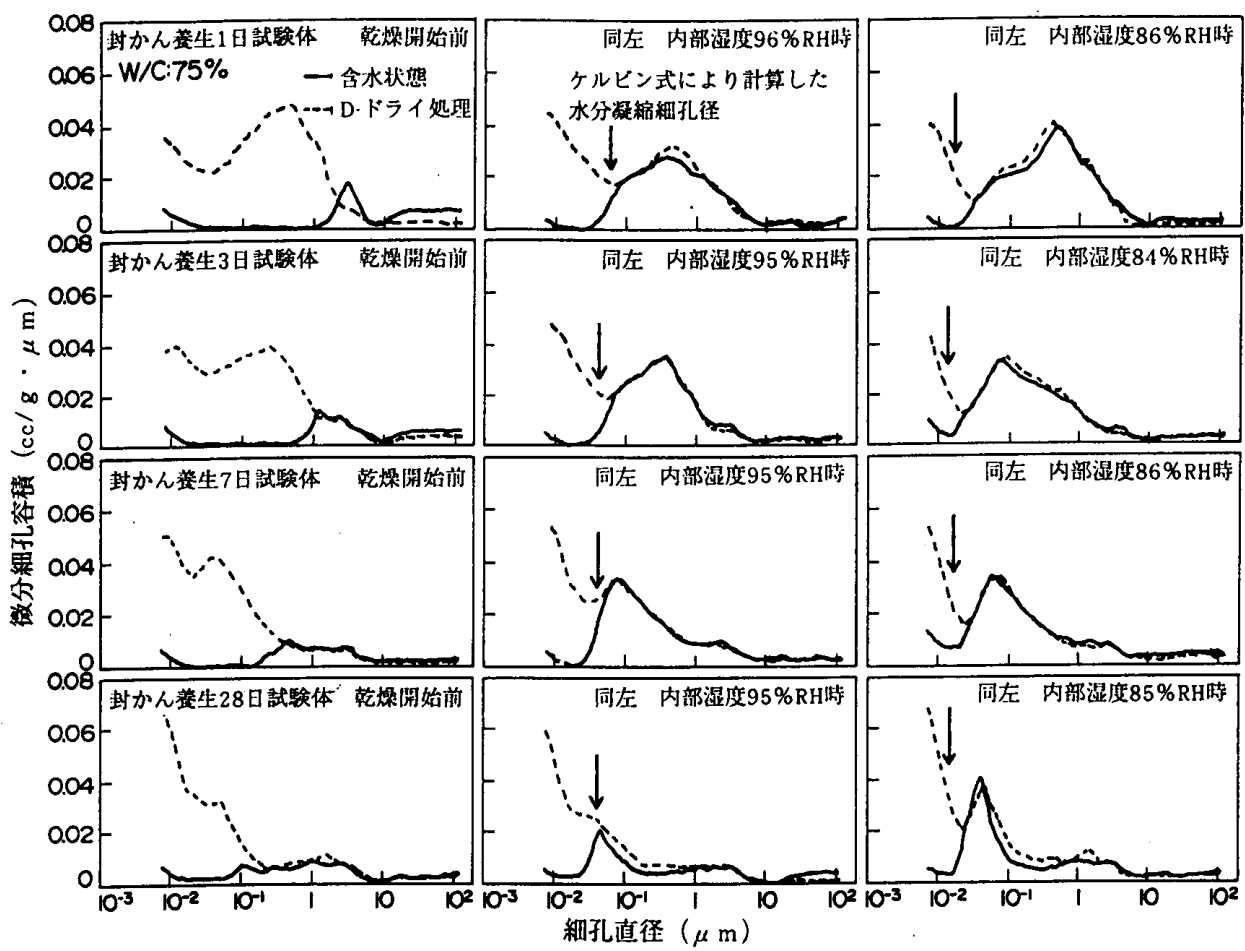

図 5 （3）含水状態と乾燥処理試験体の微分細孔容積曲線（水／七比：75\%) 


\section{6 測定結果の信賴性の檢討}

水分を含んでいる状態での測定結果及び前述の推測の 信頼性を検証するために、液相の水分が離脱しはじめる 細孔径について内部湿度データを用いたケルビン半径の 計算と、試料中の全空隙量について体積法による測定を 行った。

\section{1 水分の離脱する細孔径の検討 (ケルビン半径の 計算)}

多孔体の毛細管では、特定の細孔径より小さい領域で 水分は液相状態にあると考えられ、その細孔径は相対湿 度と関係する。ケルビン半径 $\mathrm{r} k$ は毛細管凝縮がおこる 細孔の半径として定義されるものであり、相対湿度との 関係は次式で与えられる。

$\mathrm{r}_{\mathrm{k}}=2 \gamma \mathrm{Mcos} \theta / \rho \mathrm{RT} \ln \left(\mathrm{p} / \mathrm{p}_{\mathrm{s}}\right)$

$\begin{array}{rlr}\text { ここに } \mathrm{r}_{\mathrm{k}} & : \text { ケルビン半径 }(\mathrm{m}) \\ \gamma & : \text { 液 }\left(\mathrm{H}_{2} \mathrm{O}\right) \text { の表面張力 }(\mathrm{N} / \mathrm{m}) \\ \mathrm{M} & : \text { 液 }\left(\mathrm{H}_{2} \mathrm{O}\right) \text { の分子量 }(\mathrm{kg} / \mathrm{mol}) \\ \theta & : \text { 接触角 } & \\ \rho & : \text { 液 }\left(\mathrm{H}_{2} \mathrm{O}\right) \text { の密度 } & \left(\mathrm{kg} / \mathrm{m}^{3}\right) \\ \mathrm{R} & : \text { 気体定数 } & (\mathrm{J} / \mathrm{mo} 1 * \mathrm{~K}) \\ \mathrm{T} & : \text { 絶対温度 } & (\mathrm{K}) \\ \mathrm{p} / \mathrm{p}_{\mathrm{s}} & : \text { ガスの相対压 (相対湿度 })\end{array}$

従って、この関係を用いれば湿度の測定値をもとにし て、モルタル細孔内での水分の凝縮、非凝縮の境界とな る細孔半径を計算することができる。ここではモニター 用試験体の湿度湘定値を用いてケルビン半径を求めた。 それを直径に直し、図5中にその位置を矢印で示した。 もちろんセメントモルタルでは細孔が、ケルビン半径計 算上の仮定としている円筒形ではなく、また水分の脱吸 着の機構も単純ではない。そのため分岐位置は、計算よ り求めた位置と完全に一致するものではないが、それで も $2 つ の$ 細孔分布曲線（水分を含んでいるものと乾燥し たもの）が離れはじめる位置と非常に近い位置となって いる。このことは両微分細孔曲線の分離点近傍が、水で 充填されている細孔であるか、空隙であるかの分岐点を 意味する、とした前節の推定がほぼ妥当であることを示 すものと考えられる。ただし乾燥開始前の試験体につい ては、ほぼ飽和湿度状態にあり、ケルビン半径は求めら れていない。

\section{2 全架煊量からの検討}

ここでいう体積法とは容積計（マイクロメリテックス 社製マルチボリューム1305）を用いて、定容積膨張法に より紛体、多孔性物質、不規則形状の物質など、密度の 測定しにくい試料の真体積（内部空隙を除いた体積）を

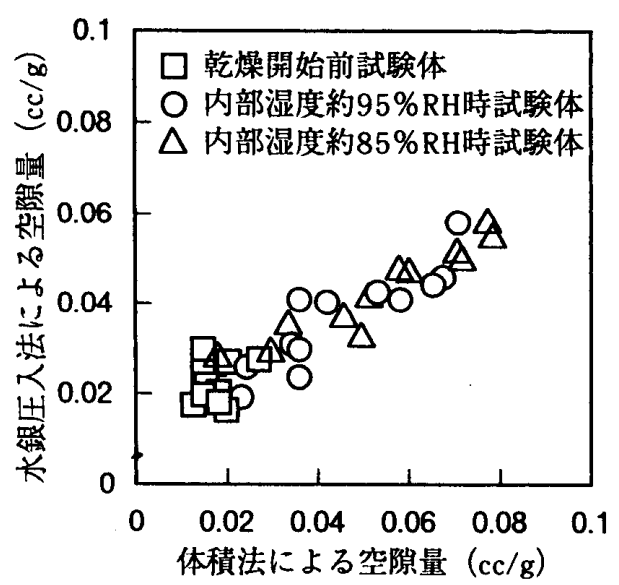

図 6 体皘法と水銀圧入法により测定した空隍量の比較

測定する方法のことである。これは測定に際し試料を乾 燥する必要がないため、水分を含んだ状態での体積測定 が可能であり、そのためここで用いた試験体のような水 分を含む状態でのモルタル内部の空隙量を、総量として 知ることができる。

その測定は、以下の手順による。まず、水分を含んで いる試料約 $100 \mathrm{~g}$ 程度の体積 $\mathrm{V}$ 、を測定する。その後試料を 2 日間水中に浸漬し、すべての空隙を水で満たす。その 状態で体皘 $\mathrm{V}$ 2を測定する。これから単位重量あたりの水 分を含んでいる状態での空隙量 $\left(V_{2}-V_{1}\right) / G 、(G$ は試料重量）を算出する。

図6に体積法により測定した全空隙量と、水銀圧入法 による測定値から計算した全空隙量を比較し示す。水銀 圧入法による測定では、細孔径の大きい領域での測定が $110 \mu \mathrm{m}$ で打ち切られ、それより大きい径の空隙量が算入 されていない。そのため体積法での測定値より全体的に 少な目の値になっているが、両測定値は試験体の種類、 乾燥条件のいかんに係わらず比較的良い相関が見られて いる。従って、ここで行った水分を含んだ試料を対象と した水銀圧入法による測定は、全空隙量の面からもほぼ 信賴性のある測定がなされているものと思われる。

\section{7 眼定結果の考察}

\section{1 水分を含む細孔の状態}

図 7 に本測定で得られた水分を含む状態と含まない状 態（Dドライ処理後）における微分細孔容積曲線を模式 的に示す。ケルビン半径の検討で述べたように、両曲線 が離れ始める位置がほぼ液相の水分が存在し始める細孔 直径であると推定される。ところでケルビン半径の定義 に従えば、下村等》"のモデルに示されるように、この径 から小さな細孔領域ではすべて水で充填されているはず であり、図8に示すようにその領域下での細孔量は完全 に零とならなければならない。

しかし本測定ではそのように急激ではなく、除々に減 
少している。セメントモルタルでは、細孔が必ずしも円 筒型モデルで説明される様な理想的な形態をしておらず そのため例えばインクボトル型空隙と呼ばれる、入口が 狭く内部に大きな空間を持つ細孔構造の存在の可能性、 あるいは水封されている細孔の奥での空隙の存在の可能 性のため、見かけ上さらに小さい細孔があるように測定 值に現れたとも考えられる。しかしながら一旦減少した 細孔容積がさらに小さい細孔径領域で增加している試料 もあり、概ねこの测定値のように空隙が存在していると みなして良いように思われる。

このことが成立すると、実質的に内部が水で充填され ている細孔は、水分を含む状態と完全に乾燥した状態で の細孔容積差として考えることができる。そこでその差 （図 7 の模式図中下図の陰影線で示す部分）を求め、図 9 に示す。この図は液相で水分が存在している細孔の情 報を与えるものとなる。

\section{2 乾燥の影響}

封かん養生から取り出したばかりの乾燥開始前の試験 体では、大きな細孔直径領域から液相の水分が存在して いるが、乾燥の進行とともに小さな細孔直径領域へと移 動し、またその容積も減少する。もちろんここでの測定 では、内部湿度約 $95 \% \mathrm{R} \mathrm{H}$ まで乾燥するのに1〜2 日、 約 $85 \% \mathrm{RH}$ まで乾燥する のに3〜 5 日程度を要する ため、その間の水和に伴う 細孔構造のち密化も進行す る。それゆえ純粋に乾燥だ けの効果が抽出されている わけではないが、例えば水 和がかなり進行したと考え られる、封かん養生 28 日 の試験体についても同様な 傾向が明瞭に見られており、 液相で水分が存在する細孔 径に及ぼす乾燥の影響は大 きいと思われる。

このことをさらに詳しく 調べるために、図 9 中の曲 線の立ち上がり位置を液相 で水分が存在し始める点で あるとみなし、その細孔直 径を整理し図10に示す。 この図より乾燥の進行にと

もない、液相で水分が存在する細孔直径は小さくなるこ とが明かである。さらに乾燥開始前に存在していた養生 期間の大きな差も狭まりお互いに近い値となる。しかも それは水セメント比の影響をそれ程受けていない。この
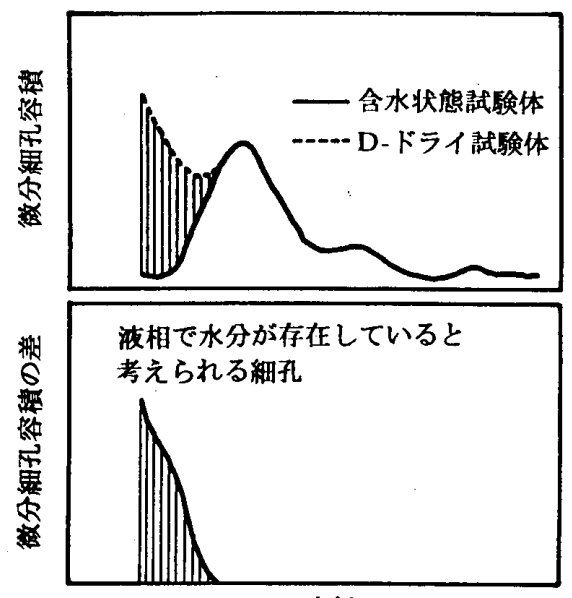

細孔直径

図 7 細孔分布の模式図と液相で水分が存在していると考えられ る細孔

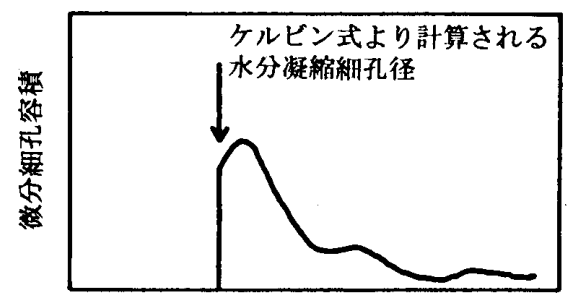

紐孔直径

図8 水分を含んている理想的なケルビン式のモデルで予想され る微分細孔容樌曲線

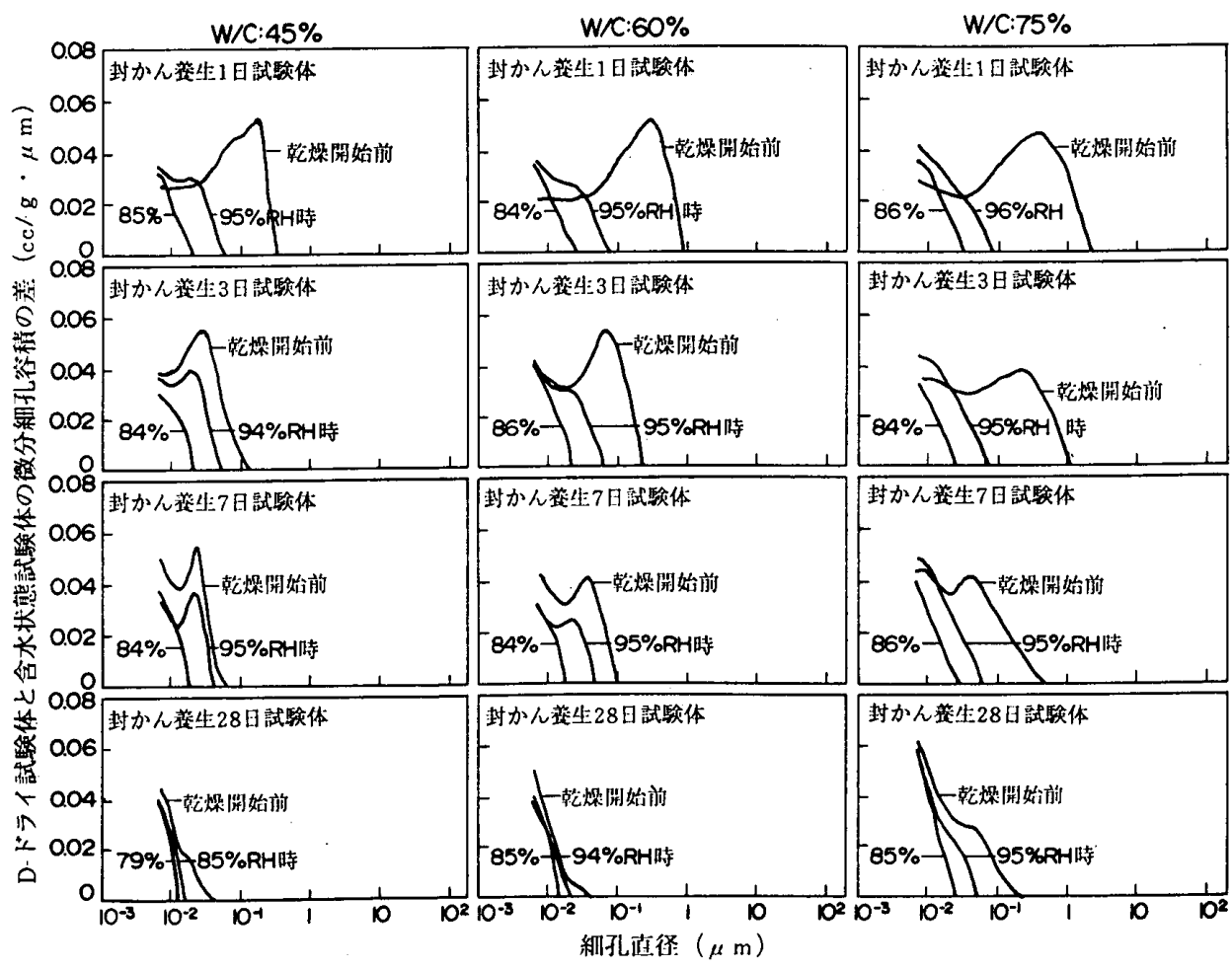

図9水分が液相で存在すると考えられる細孔の状態

ことは水分凝縮細孔直径を強く決定したのは湿度である ことを意味し、乾燥により内部湿度が低下し、そのこと が液相で水分が存在する細孔直径を小さくしたと考えら れる。 


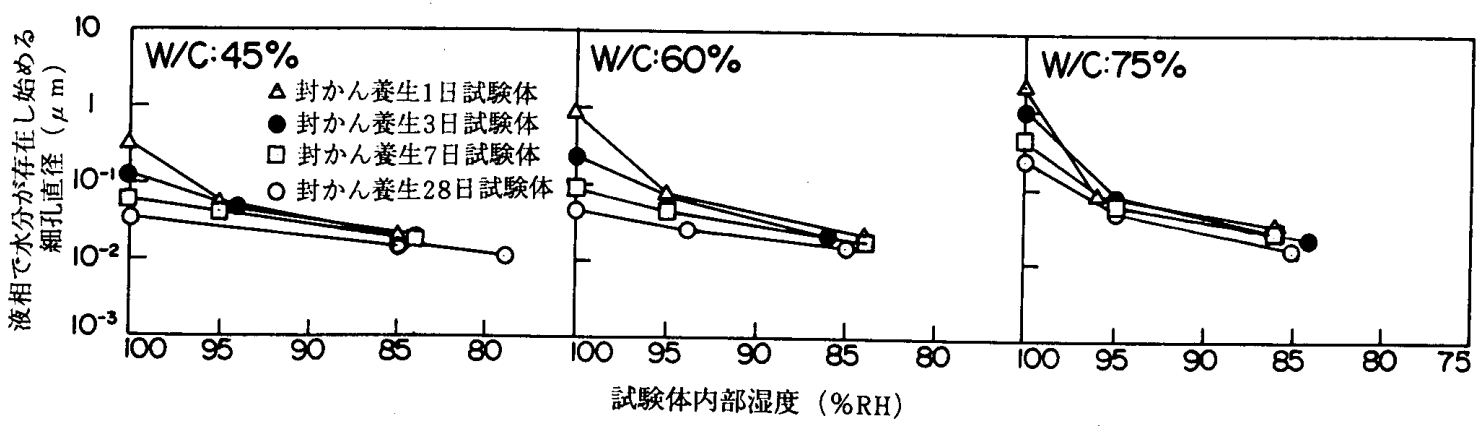

図 10 乾燥に伴う、液相で水分が存在し始める細孔直径の変化

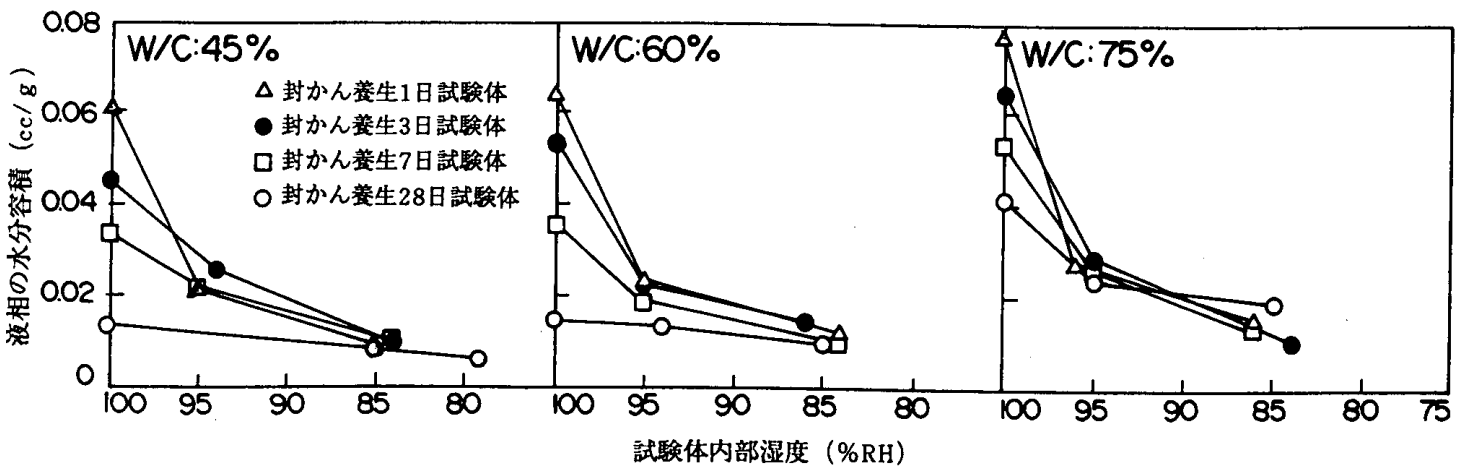

図 11 乾燥に伴う、液相の水分容積の変化

また図 9 の曲線を積分すると、測定範囲細孔直径内で の凝縮している水分の全容積が得られるが、ここではこ れを液相の水分容積と呼び図 11 に示す。液相の水分容 積も乾燥の進行に伴い急速に減少する。また乾燥開始前 に大きかった養生期間の差も狭まり、お互いに非常に近 い値となる。ただしこの場合は水セメント比の影響が顕 著に見られ、水セメント比が大きくなるに従い液相の水 分容積は増加する。この理由は試験体の水セメント比が 大きくなるとぺースト部分の細孔構造が粗になり、従っ て細孔容積も増加し、結果として試験体に保有される水 分量が多くなるためと考えられる。

\section{3 養生日数の影瞕}

封かん養生直後のまだ乾燥させていない試験体につい て、液相で水分の存在する細孔直径の養生日数による变 化を図 12 に、液相の水分容積の変化を図 13 に示す。 この試験体は封かん状態で養生されていたものであり、 水分の蒸発は防止されている。そのため湿度は飽和湿度 状態にあり、ケルビン式を用いての計算から液相で水分 の存在する細孔径を求めることはできないが、ここで述 べた D ドライ試料と含水状態試料の微分細孔容積曲線の 差を利用する方法では直接その測定が可能である。

養生日数の影響については、その日数が増すに従い液 相で水分の存在する細孔直径が小さい方に移動し、空隙 となっている細孔領域が広がる。また同時に液相の水分 容積も減少しており、これらは水分が水和のために消費 されているいわゆる自己乾燥の状態を細孔構造の面から も表しているものと考えられる。特に材噛 7 日までの、

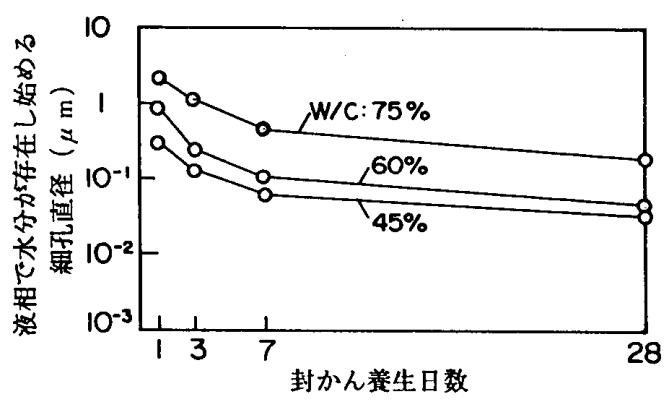

图 12 養生時間の経過に伴う液相で水分が存在し始める細孔直 径の変化

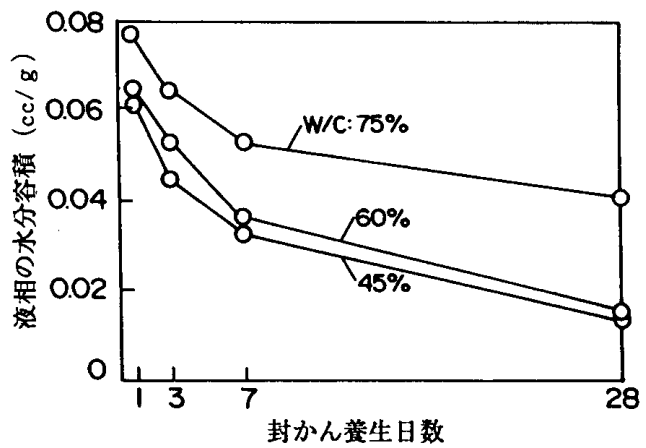

図 133 養生時間の経過に伴う液相の水分容皘の変化

液相で水分の存在する細孔直径および液相の水分容積の 急激な減少は、この期間の水和反応が非常に活発であっ たことを示すものと考えられる。

\section{8 結論}

乾燥途中の水分を含んでいる状態でのモルタルの細孔 構造について調べ、得られた結論は以下のとおりである。 
（1）水分の散逸をできるだけ押さえるために、水銀圧 入法の初期減圧を弱めた一連の测定方法を示した。これ により従来の方法では得ることの出来なかった、セメン トモルタルの水分の含まれている状態での細孔構造を知 ることを可能とした。これはケルビン半径の計算結果お よび空隙容積の测定結果との比較からも、有効な方法で あることが確認された。またこの方法は、ケルビン半径 の計算による従来の方法では困難であった飽和湿度下で の細孔の状態を知ることも可能とした。

(2) 乾燥の進行に伴い、液相で水分が存在し始める細 孔は小さい径へと移動し、液相の水分容積も減少するこ とを実験的に明かにした。

（３）封かん養生条件下でも材令が進むに従い水分は消 費されるが、ここの测定でも液相で水分の存在する細孔 径は小さくなり、同時に液相水分容積も減少することを 明かにした。これは自己乾燥の過程を細孔構造の面から 示すものと思われる。

\section{謝辞}

本研究を実施するにあたり、原田光広氏（元東京工業 大学大学院生、現在、旭化成工業（株））の協力を得ま した。また名和豊春氏（秩父セメント（株））には研究
上の有益な助言・討論をいただきました。心より感謝申 しあげます。

\section{洘考文献}

1) Hiroshi Uchikawa, Shunsuke Hanehara. Daisuke Sawaki: 3rd NCS International Seminar on Cement and Building Materials (New Dehli) Vol.4. VIII-1-12 (1991)

2) 長滝重義、米倉亜州夫: コンクリートの乾燥収粳およびクリ 一プの機構に関する考察; コンクリート工学、Vol.20, No. 12. pp. 85-95 (1982)

3) 羽原俊祐、沢木大介、内川 浩: 硬化モルタルの組織、空隙 構造と乾嬠収縮との関係（水セメント比と前養生期間の影響） ; セメント・コンクリート論文集. No. 45, pp.280-285 (1991)

4) 鉷田英治、大内一之、吉野利幸：硬化セメントペーストの凍 害と細孔構造の役割について；セメント技術年報、NNo. 30 . pp. 292-295 (1976)

5) 長滝重義、氏家 勲: コンクリートの透気性の定量的評価に 関する研究；土木学会諭文集， No. 396,V-9,pp.79-87(1988)

6 ) H. H. Reinhardt, K.Gaber:From pore size distribution to an equivalent pore size of cement mortar: Materials and Structures, No.23, pp. 3-15(1990)

7) 下村 匠、小沢一雄: 細孔構造モデルによるコンクリート中 の水分移動解析； コンクリート工学年次論文報告集、Vol.14。 No. 1, pp.631-636 (1992)

8 ）近藤連一：多孔材料、技報堂 (1978)

(1993 年 10 月 8 日原稿受理, 1994 年 4 月 1 日採用決定) 